\title{
The Relation of Fiscal Decentralization, Regional Finance and Social Justice for the Local Development of Indonesia
}

\author{
Timbul Hamonangan Simanjuntak ${ }^{1}$, Imam Mukhlis ${ }^{2}$ \\ ${ }^{1}$ Faculty of Economics, Maranatha Christian University, Indonesia \\ ${ }^{2}$ Faculty of Economics, Universitas Negeri Malang, Indonesia \\ Correspondence: Timbul Hamonangan Simanjuntak, Faculty of Economics, Maranatha Christian University, Prof. Drg. \\ Surya Sumantri Street No.65, Bandung, West Java, 40164, Indonesia.
}

Received: August 31, 2016

Accepted: September 12,2016

Available online: October 6, 2016

doi:10.11114/aef.v4i1.1911

URL: http://dx.doi.org/10.11114/aef.v4i1.1911

\begin{abstract}
This study aims to analyze the relationship between fiscal decentralization, fiscal capacity, financial independence and financial expenditure areas in achieving social justice. In this case, the East Java Province Indonesia is supported by the existence of local government district / municipality became the main object of study during $2010-2014$. The needed data are such as; financial balance data, regional revenue, the amount of local spending and social justice data on people's lives. Data analysis method used is Partial Least Square (PLS). The results provide the conclusion that the implementation of the fiscal decentralization policy gives positive and significant impact on local fiscal capacity. Fiscal capacity gives positive and significant impact on the local financial independence. Local financial independence gives positive and significant impact on the structure of the shopping area. The structure of local government spending has a significant effect on the achievement of social justice areas. In this case, the fiscal capacity and financial independence have no direct impact significantly on the achievement of social justice in the various districts / cities in East Java. In addition, this study also provides important conclusion that there is a significant indirect effect of fiscal decentralization on social justice through local fiscal capacity, local financial independence and the structure of local government spending.
\end{abstract}

Keywords: fiscal decentralization, fiscal capacity, financial independence, social justice, partial least square

\section{Introduction}

The nowadays national development is faced with the constellation of the world economy which unluckily is uncertain, so the impact on the continuity and stability of the economy of the region's economy. Foreign debt crisis, world's monetary fluctuation, and the international oil price shock suggests that the world economy's dependence is a two-way relationship. These events do not only signify the nature of the dependency relationships between developing countries on rich countries, but also for the rich country's dependence on developing countries and poor countries. So that by itself increases the levels of interdependence or interdependence among all countries of all nations who are members of the international social system. Dynamics in Indonesia's economic development can not be separated from the situation such relationship. On the same side of local economic development in Indonesia can not be separated from the existence of other areas which are mutually dependent on each other as a unitary state consisting of various regions as a unitary state of Indonesia.

In fact, local economic development in Indonesia it still leaves the problem of income gap is very sharp, in addition to other problems, the employment and high levels of poverty. Indonesia's economic activities concentrated in Java and Sumatra islands. Both of these regions controls $81.4 \%$ of the total economy and other areas which only gained $18.6 \%$. This fact shows the gap is very high. Indonesian Central Bureau of Statistics (BPS) data showed the progress of Indonesia's GDP growth reached an average of 6.2 percent in 2011 (BPS, 2012) and also rise in 2012. But this figure does not impact on the people prosperity (Gini Ratio $0.41 \%$ ), which illustrates the inequality that is very serious. As known in Gini Ratio index Indonesia continues to increase each 0.37 in 2008, 0.38 in 2009 and 0.41 in 2011 (BPS, 2012). This phenomenon illustrates that the economic growth of data is simply false, the GDP indicator does not describe the real situation. Indonesia's economic development goals are oriented to the increase in GDP. Though there are serious problems in the GDP statistics and benchmarks of development does not only shown by GDP per capita. 
The implementation of fiscal decentralization brings about changes in the local government budgeting mechanism. In this case through the grant system as grants, the components in the national and regional budgets change. In the state budget expenditure components contained glide grant as grants. While the components of the budget receipts both level I and level II contained glide grant as grants from the central government. Through the mechanism of this budget, is expected to create efficiency, innovation and encouraging competition among local governments in achieving economic growth and the welfare of society (Oates, 1999).

In the implementation, fiscal decentralization is in the form of allocation of equalization funds pose their fiscal disparities (fiscal disparity) (Allers and Ishemoi, 2011). This fiscal disparities can occur because local governments are not able to produce comparable services at comparable tax rates. Fiscal disparities appear either on the revenue side or on the expenditure side of the budget (Ladd, 1994). In this case the area with affluent population are usually better able to finance the provision of a public good in other areas. This is because the region with affluent population could increase tax revenue more easily (Allers and Ishemoi, 2010).

This fiscal disparities could lead to the occurrence of inequality and inefficiency in resource allocation (Boadway, 2004). This happens because each region does not have the same ability to explore the potential of its resources. Besides, that inequality may occur due to factors of production that there can not be allocated efficiently. In this case, the capital and labor that is more centrally located in an area with a high net fiscal benefit and not on productivity areas with the highest production factors. As a result there is a gap in the allocation of the budget required in fulfillment of goods and services for the people. The degree of this gap will get bigger when the posture in the regional budget (APBD) did not attend to the basic necessities of life in society. The implications of fiscal disparities is a resident of an area can receive services in public good provision better than a tax that has been paid. Meanwhile, residents of other regions have not received services in public good provision better than any tax already pays (Allers and Ishemoi, 2010).

The issue of the gap in the budget of the region has serious implications in the management and implementation of state governance in Indonesia. Heterogeneity area with different social characteristics, economic and cultural enormous reflects the potential for problems is significant in the balance in the budget between regions. To overcome the problem of fiscal disparities among regions can be performed by compensating area with expenditure needs and fiscal capacity is low. This can be done by equalization transfers, both horizontal and vertical equalization equalization. According to Allers and Ishemoi (2010) equalization has two components, namely the equalization of fiscal capacity and expenditure needs equalization.

In order to achieve economic growth of the region, the role of local budgets is very important. Through the local budgets, local governments can be allocated part of their income to improve public services. Budgeting mechanism in this area involves stakeholders in determining priorities and the magnitude of the required budget ceiling in the financing of public service delivery. In this case the utilization of economic resources and local finances is an important factor in supporting the implementation of the fiscal decentralization system in the area. However, the implementation of fiscal decentralization may cause the happening of fiscal disparities and inequities utilization of factors of production (economic resources) that exist in the area. This inequality can lead to a fiscal capacity that is uneven between regions, so that local financial independence to be disrupted in supporting the achievement of regional economic growth.

Social justice is the ideals of national development as implied in the preamble of the Constitution of 1945. In achieving social justice for communities to do with various strategies implemented in national development. Implementation of the Fiscal Decentralization Policy in place since 2000 in the country's financial management system (APBN) and regional finance (budget) is expected to encourage the creation of social justice for local people. Through these policies, the central government budget allocation as grants for the provincial government and district / city in Indonesia. In this case the province of East Java is one of the areas that has implemented a policy of fiscal decentralization. With the status of a province that has a level of regional economic growth at an above average rate of national economic growth, East Java has the potential to improve the achievement of social justice for the people. This can be done when fiscal decentralization can strengthen regional financial aspects (fiscal capacity and financial independence) which can increase the budget allocation for the construction of regional communities achieve social justice.

As illustrated, for 2010-2014 equalization fund that transferred from central government to regional government in province of the East Java increasing. The progress of equalization fund that received by regional governance in East Java as below : 
Table 1. The amount of equalization funds transfer in the Province of East Java, Indonesia

\begin{tabular}{ll}
\hline Year & Equalization Fund (IDR) \\
\hline 2010 & $25,279,389,373,000$ \\
2011 & $27,311,860,624,000$ \\
2012 & $32,538,241,633,000$ \\
2013 & $35,130,364,839,000$ \\
2014 & $38,533,235,741,000$ \\
Total & $158,793,092,210,000$ \\
\hline
\end{tabular}

Source: www.djpk.kemenkeu.go.id

\section{Formulation of the Problems}

Based on the description of the background, it can be formulated the research problem as follows:

1) Does fiscal decentralization significantly effect on local fiscal capacity?

2) Does local fiscal capacity significantly effect on local financial independence?

3) Does local fiscal capacity significantly effect on local government spending structure?

4) Does the local financial independence significantly effect on the structure of local government expenditure?

5) Does the local financial independence significantly effect on local community social justice?

6) Does the structure of local government expenditure significantly effect on local community social justice?

7) Does local fiscal capacity significantly effect on the local community social justice?

\section{Literature Review}

Fiscal decentralization is a consequence of the practice of democratization in the country's financial management. Through these policies, the relationship between the central government and local governments can be directed at welfare of society that promote equitable development and social justice in the various countries. As the existing theories that decentralization generally means the devolution of decision-making powers. A related concept is "deconcentration," in which operations are decentralized, but decision-making powers are not devolved. For example, many observers state that Bangladesh is a deconcentrated system, in the which local Governments are still subject to the control of central authorities, as opposed to a decentralized one, in the which local Governments have autonomy to set Reviews their own priorities and Decide how best deliver public services. In addition, decentralization does not necessarily denote an erosion of central control nor of powers over national issues and processes with dimensions (Martinez-Vazquez, 2011).

The mandate of the law of 1945, especially article 33 provides an important emphasis will be managing the economy and the existing resources for the greater welfare of the Indonesian people. In connection with this basically financial management of the State can be directed at achieving the welfare of local communities. In this case the fiscal decentralization policy applied in Indonesia in the 2000s referring to the Law No. 25, 1999 basically will re-emphasize the identity of economy based on the principles of deliberation and consensus. In this case the fiscal decentralization is a policy in relation to the financial management of the central government and local governments. According to Oates (2006) in the traditional theory of public finance described the role of fiscal dencetralization. The role can be explained further in the function of resource allocation in the public sector. Meanwhile, according to Tanzi (1995) fiscal decentralization showed the delegation of authority in the public finances and service delivery from central government to the regions. Devolution is related to four things which are;

a. Expenditure decisions;

b. Taxing and revenue-raising powers;

c. Subnational borrowings and

d. Intergovernmental fiscal transfers.

The role of fiscal decentralization in improving development performance can be measured by the degree of achievement of social justice that is felt by the whole society. In the context of national development, social justice explicitly an important part of the state ideology of Pancasila mainly to the five precepts which reads "... Social justice for sleuruh Rakyat Indonesia...". Beside that social justice is also a mandate of the Constitution (Constitution) 1945 which emphasized the importance of achieving a just and prosperous society in the achievement of the independence of 
Indonesia. In this case social justice reflects their level of prosperity achieved by the community life by making use of economic resources and also the state's role in regulating countless lives. 1945 Constitution explicitly set the livelihood of the people in the form of meeting the needs of education and the right to a decent life, providing employment and poverty alleviation in the life of Indonesian society.

Various studies have been conducted to analyze the impact of decentralization on the development goals of a country. Results of research conducted by Pose and Krøijer (2009) in the European countries of interest to be analyzed. The research conducted in the period 1990-2004 in various European countries, particularly in Central and Eastern Europe. The analytical method used was panel data. The results of his research to the conclusion that fiscal decentralization has a negative correlation with economic growth in many countries in Europe. Results of another study by Dincecco and the Prado (2010) gives the conclusion their positive influence and significant correlation between the magnitudes of the fiscal capacity to finance budget expenditures penddikan sector in 111 countries in the period 1975-2004.

Sukanto and Muhklis (2013) tried to explore further the relationship between financial independence and well-being of the people living in South Sumatra Indonesia during 2006-2010. Based on the analysis done may be produced conclusions that local financial independence has a negative effect on the level of poverty and reverse the level of local financial independence has a positive effect on the welfare of living (measured by the Human Development Index) community districts / cities in South Sumatra. While Simanjuntak and Mukhlis (2015) in his research resulted in a conclusion that there is a negative and significant effect of fiscal decentralization on the fiscal capacity of local government district / city in East Java, Indonesia. Beside, it also showed a positive and significant influence between the fiscal capacities to financial independence.

Sacchi and Salotti (2014a), investigating the effects of fiscal decentralization on household income inequality, for a sample of 23 OECD countries over the period of 1971-2000, find that a higher degree of tax decentralization is associated with a more unequal distribution of income within a country. More recently, Sepúlveda and Martinez-Vazquez (2011) proved that higher levels of fiscal decentralization appears to reduce poverty as long as the share of sub-national expenditure is not greater than one-third of total government expenditure.

Various studies have been conducted to analysize empirical link between fiscal decentralization, local finances and the welfare of society. But among the various studies that there is no specifically relate to the fiscal decentralization of social justice. This is important, because basically justice is one of the basic things that are needed by the community in the process of development. Perspective of development is not only oriented to growth per se, but also aimed at creating equity and social justice for the whole society. Financial decentralization to local governments already should be able to increase the prosperity of the people and social justice in a country.

\section{Hypothesis}

Based on the description of the background and the formulation of the problem, it can be formulated as the following research hypothesis:

1) Fiscal decentralization has a significant effect on local fiscal capacity

2) Local fiscal capacity has a significant effect on local financial independence

3) Local fiscal capacity has a significant effect on the local government expenditure structure

4) Local financial independence has a significant effect on the local government expenditure structure

5) Local financial independence has a significant efect on local community social justice

6) The local government expenditure structure has significantly effect on local community social justice

7) Local fiscal capacity has a significant effect on local community social justice

\section{Method}

This research is explanatory research in which the method of research is aimed to conduct a study and analysis of the inter-relationship between the variables which were observed. The data in this study of secondary data, which is taken in the time series time series from 2010 to 2014 and cross sectional covers 38 districts / cities in East Java Province, Indonesia. Data obtained from the documentation relevant agencies, include: the Central Statistics Agency of East Java Province, the Tax Office, the Finance Ministry website (www.djpk.kemenkeu.go.id) and the Central Statistics Agency website (www.bps.go.id). Methods of data analysis using Partial Least Square (PLS). Data used in the study include:

1) Fiscal Decentralization (X1) is a system of government financing within the framework of a unitary state, which includes the distribution of revenues between the central and regional governments as well as the equitable distribution among the regions in proportion, democratic, fair and transparent with regard to the potential, conditions and needs of the region in line with the obligations and the distribution of authority as well as the procedure for the 
organization of such authority, including management and financial oversight. The indicators used in this study include:

- Tax Revenue (X11)

- General Allocation Fund (X12)

- Specific Allocation Fund (X13)

2) Local Fiscal Capacity (Y1) is the amount of the budget capacity which is owned by the local government in public financial management in order to finance the implementation of regional development (of Tennessee Advisory Commission on Intergovermental Relations, 2005). To assess the size of this area using a fiscal capacity indicator (Besley and Persson, 2009a; Dinecco and Prado, 2010):

- The ratio of local tax to the Gross Regional Domestic Product (GRDP) (Y11)

3) Local Financial Independence (Y2) is the level of local financial independence in the financing of development in the region. The degree of financial independence of an area can be calculated with the following formula is (www.djpk.depkeu.go.id):

$\mathrm{KKDi}=\mathrm{PAD}_{\mathrm{i}} / \mathrm{TP}_{\mathrm{i}}$, in which $\mathrm{KKD} \mathrm{I}$ is a regional financial, PAD is the Local Revenue $\mathrm{i}$ and TP is the total income of region $\mathrm{i}$ (Y21).

4) Local Government Expenditures Structure (Y3) is the amount of allocations issued by local governments to finance the execution of construction. Government expenditure is limited to the budget, and therefore productive expenditure (spending on public services, expenditure on education, spending on health expenses for transport and communications as well as expenditure for housing) will increase economic growth. Instead of unproductive expenditure (expenditure for social security, spending on recreation and other consumer spending) does not increase economic growth. Indonesia budget in line with the post of regional autonomy, the ratio of spending part of routine expenditure and development expenditure of the budget (APBD) provided an indicator existing capabilities in the area. The indicators are:

- Routine Expenditure (Y31), the amount of expenditures of personnel expenditure in the budget.

- Capital Expenditures (Y32), which is the amount of capital expenditures and expenditures for goods and services in the budget.

5) Social Justice (Y4) is the level of success in economic development as measured from various aspects. The indicators are: Inequality of Income (Y41), Poverty (Y42), and Employment (Y43)

\section{Results}

PLS analysis results can be interpreted into structural models. Structural model presents the relationship between the study variables. Coefficient structural model of stating the magnitude relationship between the variable to another variable. There is significant influence between variables one to another variable, if the value of P-value of $<0.05$. In PLS are two influences that direct effect, as well as indirect effect results of direct influence can be seen in the following table.

Table 2. Structural PLS Model: Direct Effect

\begin{tabular}{llll}
\hline Relationship & Coefficient & t-statistic & P-value \\
\hline $\begin{array}{l}\text { Fiscal Decentralization (X1) on Local Fiscal } \\
\text { Capacity (Y1) }\end{array}$ & 0.342 & 6.006 & 0.000 \\
$\begin{array}{l}\text { Local Fiscal Capacity (Y1) on Local Financial } \\
\text { Independence (Y2) }\end{array}$ & 0.347 & 6.917 & 0.000 \\
$\begin{array}{l}\text { Local Fiscal Capacity (Y1) on Local } \\
\text { Government Expenditure Structure (Y3) }\end{array}$ & 0.267 & 5.210 & 0.000 \\
$\begin{array}{l}\text { Local Fiscal Capacity (Y1) on Social Justice } \\
\text { (Y4) }\end{array}$ & 0.066 & 1.121 & 0.262 \\
$\begin{array}{l}\text { Local Financial Independence (Y2) on Local } \\
\text { Government Expenditure Structure (Y3) }\end{array}$ & 0.512 & 11.799 & 0.000 \\
$\begin{array}{l}\text { Local Financial Independence (Y2) on Social } \\
\text { Justice (Y4) }\end{array}$ & 0.063 & 1.116 & 0.265 \\
\hline $\begin{array}{l}\text { Local Government Expenditure Structure (Y3) } \\
\text { on Social Justice (Y4) }\end{array}$ & 0.623 & 11.650 & 0.000 \\
\hline
\end{tabular}

Source: Processed Primary Data, 2016 
GThe structural PLS model can be seen the following figure:

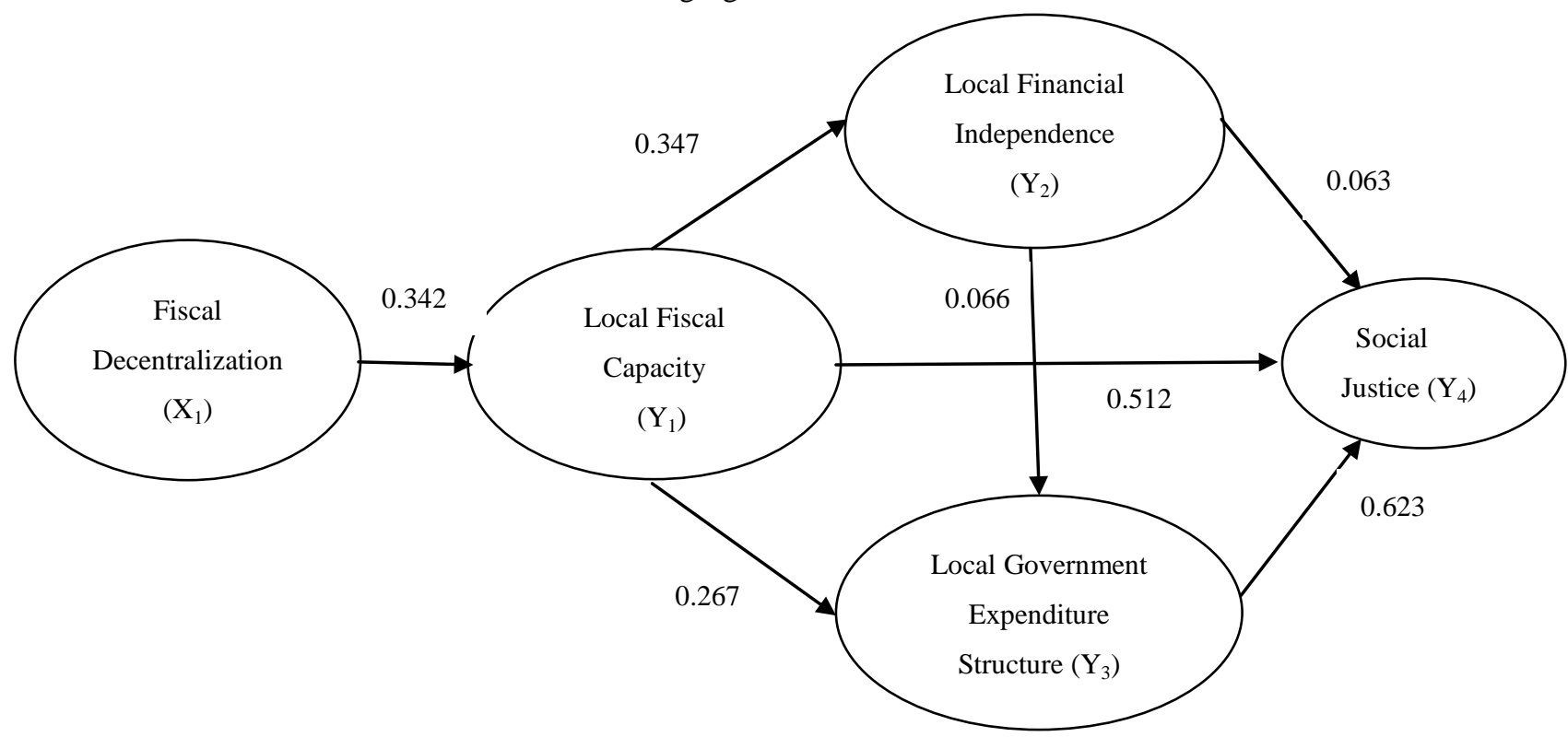

Figure 1. PLS Structural Model

In addition to the direct effect of the test, the PLS also known as indirect effect. The indirect effect is the result of multiplying two (2) direct influence. The indirect effect is declared significant if both the direct influence that shape is significant. Here is presented the results of the indirect effect:

Table 3. PLS Model: Indirect Effect

\begin{tabular}{lllr}
\hline Indirect Effect & Coefficient of Direct Effect & & $\begin{array}{c}\text { Coefficient of } \\
\text { Indirect Effect }\end{array}$ \\
\hline $\mathrm{X} 1 \rightarrow \mathrm{Y} 1 \rightarrow \mathrm{Y} 2$ & $\mathrm{X} 1 \rightarrow \mathrm{Y} 1=0.342 *$ & $\mathrm{Y} 1 \rightarrow \mathrm{Y} 2=0.347^{*}$ & 0.119 \\
$\mathrm{X} 1 \rightarrow \mathrm{Y} 1 \rightarrow \mathrm{Y} 3$ & $\mathrm{X} 1 \rightarrow \mathrm{Y} 1=0.342 *$ & $\mathrm{Y} 1 \rightarrow \mathrm{Y} 3=0.267 *$ & 0.091 \\
$\mathrm{X} 1 \rightarrow \mathrm{Y} 1 \rightarrow \mathrm{Y} 2$ & $\mathrm{X} 1 \rightarrow \mathrm{Y} 1=0.342 *$ & $\mathrm{Y} 1 \rightarrow \mathrm{Y} 2=0.347^{*}$ & 0.038 \\
$\rightarrow \mathrm{Y} 3 \rightarrow \mathrm{Y} 4$ & $\mathrm{Y} 2 \rightarrow \mathrm{Y} 3=0.512^{*}$ & $\mathrm{Y} 3 \rightarrow \mathrm{Y} 4=0.623 *$ & 0.057 \\
$\mathrm{X} 1 \rightarrow \mathrm{Y} 1 \rightarrow \mathrm{Y} 3$ & $\mathrm{X} 1 \rightarrow \mathrm{Y} 1=0.342 *$ & $\mathrm{Y} 1 \rightarrow \mathrm{Y} 3=0.267 *$ & \\
$\rightarrow \mathrm{Y} 4$ & $\mathrm{Y} 3 \rightarrow \mathrm{Y} 4=0.623 *$ & & 0.178 \\
$\mathrm{Y} 1 \rightarrow \mathrm{Y} 2 \rightarrow \mathrm{Y} 3$ & $\mathrm{Y} 1 \rightarrow \mathrm{Y} 2=0.347 *$ & $\mathrm{Y} 2 \rightarrow \mathrm{Y} 3=0.512 *$ & 0.166 \\
$\mathrm{Y} 1 \rightarrow \mathrm{Y} 3 \rightarrow \mathrm{Y} 4$ & $\mathrm{Y} 1 \rightarrow \mathrm{Y} 3=0.267 *$ & $\mathrm{Y} 3 \rightarrow \mathrm{Y} 4=0.623 *$ & 0.319 \\
$\mathrm{Y} 2 \rightarrow \mathrm{Y} 3 \rightarrow \mathrm{Y} 4$ & $\mathrm{Y} 2 \rightarrow \mathrm{Y} 3=0.512 *$ & $\mathrm{Y} 3 \rightarrow \mathrm{Y} 4=0.623 *$ & \\
\hline
\end{tabular}

Source: Processed Data, 2016. Note: * Significant

\section{Discussion}

The results of this study generally concludes that the implementation of the fiscal decentralization policy gives positive and significant impact on local fiscal capacity. Fiscal capacity positive and significant impact on the local financial independence. Local financial independence gives positive and significant impact on the structure of the shopping area. The structure of local government spending significant effect on the achievement of social justice areas. The existence of a direct relationship between the variables of fiscal decentralization, local finance and social justice above variables showed effectiveness in the implementation of regional autonomy and fiscal desentralsasi in various areas in East Java province of Indonesia in the period of 2010-2014. The effectiveness of these policies can be seen from the amount of the allocation of equalization funds allocated from central government to local governments. As an illustration, in 2014 the cumulative balance large amount of them (the general allocation fund, earmarked grants and tax sharing) received East Java province in 2010 approximately IDR 25 trillion. Developments in 2014 the amount of equalization funds were transferred from central government to local government district / city in East Java increased to approximately IDR 38 trillion. In the period 2010-2014 there has been a 52.4\% increase in the budget as grants in various districts / cities in East Java. The increase in the acceptance of equalization funds is also followed by an increase in expenditure in the area 
of financial structure (APBD). In 2010 the amount of expenditure (personnel, capital, goods and capital expenditures) in various districts / cities in East Java province rose by IDR 12.2 trillion to IDR 47.5 trillion. In the period 2010-2014 there has been a rise in the allocation of local government expenditures amounted to $288.21 \%$ in various districts / cities in East Java (data obtained from the website of the Finance Ministry of the Republic of Indonesia (www.djpk.kemenkeu.go.id). As reported in the research Dincecco and the Prado (2010) which gives a conclusion is positive and significant influence between the fiscal capacity to the amount of budget expenditures to meet community needs. The greater the ratio of local tax / GRDP will give greater powers to local governments in the management and allocation of budget. This is in accordance with the basic principles of the policy of regional autonomy and fiscal decentralization that emphasizes their discretion on a variety of matters that can be done by local governments independently and autonomously.

The amount of budget allocation is also accompanied by the strengthening of the institutional aspects of the financial management area refers to the principles of good governance. In Law Number 17 Year 2003 on State Finance mentioned that finance is all the rights and responsibilities which can be measured by money, and everything, in cash or in kind which could be used as a state related to the implementation of rights and obligations. In this case the local financial management set out in the Regulation of the Home Affair Minister No. 13 of 20013 Article 3 includes the power of financial management, general principles and structure of the budget, the preparation of the draft budget, the determination of the budget, preparation and adoption of the budget for areas that do not have a parliament, implementation budget, budget changes, cash management, financial administration of the region, the area of financial accounting, accountability of the budget, the guidance and supervision of financial management, a loss of area, and the financial management of Public Service Agency (BLUD).

Besides, budget allocations are received by the local government has already set up its allocation for regional development. This is seen in the provision of balance funds in the form of General Allocation Fund and Special Allocation Fund, both forms of the equalization fund allocation has special specifications in the practice of financing for development in the area.

Other results in this study indicate that the fiscal capacity and financial independence have no direct impact significantly to the achievement of social justice in the various districts / cities in East Java. But it is going on is a significant indirect effect of fiscal decentralization on social justice through local fiscal capacity, local financial independence and the structure of local government spending. The results of this study provide important implications in determining the area of financial management policies in promoting social justice for all people. Implementation of fiscal decentralization policy can basically be a positive influence on social justice by strengthening the financial management aspects of the area. In this case, the local financial management accountable and professional will be able to encourage the allocation of local budgets expenditure (budget) that the greater the quality of the implementation of the program. In terms of management of the budget, the orientation of target achievement is the strengthening of the capacity and the greater financial independence. As stated by Ali, et al (2015) limited that fiscal capacity poses a significant challenge in developing countries. In this case the greater fiscal capacity would be able to push the reception area from various financial sources in the area.

Similarly, more and more independent regional financial level, then it can increase the financial capacity of the region in exploring the potential of local revenues to finance greater regional development. This implies that the government should strengthen its fiscal policy to encourage more creative in the area of revenue generation primarily sourced from local revenue. As said by Beer-Tóth (2009) that regarding local budget autonomy, theory specifies that a weak local budget policy can seriously compromise the stability of the national economy. Therefore, the strengthening of fiscal policy can be focused on the ability of local government officials in establishing a regional admission system based on the economic potential of the region. So that resources can be optimized reception reception area either through instruments of local taxes, regional retribution or other receiving instrument authorized by the Act. In this case according to Elena (2015) that revenue autonomy implies the freedom of local authorities to decide about the source and volume of resources that finance local public goods and services, about the way are distributed among the various spending purposes, and about the way in the which the fiscal burden is shared among taxpayers. The ability of local governments to improve the reception area will be able to facilitate local regulations for implementing the development programs that meet priorities to achieve the prosperity of local community life.

In relation to the allocation of local budgets (local expenditure budget), then the financing budget for public goods provision is a priority in the fulfillment of welfare and social justice. Besides that regional financial allocations for spending on goods, services and capital spending can be directed at meeting the needs of life and the creation of jobs is increasingly widespread in various regions. In this case based on the results of research by Abdon, et al (2014) showed that that the composition of government spending also has a significant effect on economic growth. More specifically, our analysis indicates that shifting public spending to education will yield a sizable dividend growth. Emphasis budget 
allocation to meet the needs of education or health can be done based on priority in accordance with local needs. In this case based on the available data suggests that the population of East Java province in 2014 amounted to 38,610,202 people need a variety of subsistence (www.bps.go.id). The fundamental requirement is primarily related to the field of education, health, physical infrastructure and public facilities.

\section{Conclussion and Recomendation}

The implementation of fiscal decentralization policy is embodied in the form of allocation of financial balance of the central government to local governments. The transfer of these funds may have an impact on the fiscal capacity and financial independence of the areas required for the achievement of social justice. Regional financial developments in various districts / cities in Indonesia East Java province to show an increase in both the reception and the balance funds in the area of financial expenditure allocation in the period 2010-2014. The results of empirical studies in this research concludes that implementation of the fiscal decentralization policy gives positive and significant impact on local fiscal capacity. Fiscal capacity has a positive and significant impact on the local financial independence. Local financial independence has positive and significant impact on the structure of the expenditure area. The structure of local government expenditure significant effect on the achievement of social justice areas. In this case the fiscal capacity and financial independence have no direct impact significantly to the achievement of social justice in the various districts / cities in East Java. In addition, also in this study also provides important conclusion that there is a significant indirect effect of fiscal decentralization on social justice through local fiscal capacity, local financial independence and the structure of local government expenditure. Based on these findings, it can produce a wide range of development policy formulation in areas such as the following:

1) The determination of the allocation of equalization funds can take the level of achievement of social justice in society. In formula calculating equalization funds need to be included degree of social justice that exist in each region to serve as the basis for the allocation of matching funds.

2) Strengthening fiscal capacity can be done by way of the local tax revenue optimization. It can be operated through the expansion of taxpayer, the taxpayer and the tax object in the area. Search in detail needs to be done to avoid tax evasion and tax avoidance in the tax collection area.

3) Increased regional financial independence can be done by way of expansion of economic activity coupled with mapping the potential reception of regional revenue. The existence of Regional-Owned Enterprises can be managed in a transparent and accountable in order to contribute to the regional avenue. Simplifying the voting system, the existence of sanctions and rewards that can clearly improve opportunities to increase local revenues.

\section{References}

(2011). Equalising spending needs of subnational governments in a developing country: the case of Tanzania, Environment and Planning C: Government and Policy 2011, 29, 487-501. http://dx.doi.org/10.1068/c09192r

..(2006). On the Theory and Practice of Fiscal Decentralization, IFIR Working Paper No. 2006-05, May

Abdon, A., Gemma, B. E., Minsoo, L., \& Donghyun, P. (2014). Fiscal policy and growth in developing Asia, $A D B$ Economics Working Paper Series, No. 412, October, 1-24.

Ali, M., Abdulaziz, B. S., Abebe, S., \& Firew, W. (2015). Building fiscal capacity in developing countries: Evidence on the role of information technology, CMI Working Papers, WP 2015:12, October, 1-30.

Allers, M. A., \& Lewis, J. I. (2010). Fiscal Capacity Equalisation in Tanzania, Local Government Studies, 36, 697-713. http://dx.doi.org/10.1080/03003930.2010.506981

Beer-Tóth, K. (2009). Local Financial Autonomy in Theory and Practice. The Impact of Fiscal Descentralization in Hungary, Doctoral Thesis, University of Fribourg Switzerland, Fribourg, downloade from http://arsa-conf.com/archive/?vid=1\&aid=3\&kid=60301-10\&q=f1 ,at August,12, 2015

Besley, T., \& Persson, T. (2009a). The Origins of Sstate Capacity: Property Rights, Taxation, and Politics, American Economic Review, 99(4),1218-1244. http://dx.doi.org/10.1257/aer.99.4.1218

Boadway, R. (2004). The Theory and Practice of Equalization, CESifo Economic Studies, 50(1), 211-254. http://dx.doi.org/10.1093/cesifo/50.1.211

Elena, R. (2014). Comparing Local Financial Autonomy Across the European Union, Paper, Advanced Research in Scientific Areas, downloaded from http://www.arsa-conf.com,at August,13, 2016

Ladd, H. F. (1994). Measuring disparities in the fiscal condition of local governments, dalam J.E. Anderson (red), Fiscal equalization for state and local government finance, (Westport: Praeger),21-54 
Martinez-Vazquez, J. (2011). The Impact of Fiscal Decentralization Issues in Theory and Challenges in Practice, Asian Development Bank

Oates, W. E. (1999). An Essay on Fiscal Federalism, Journal of Economic Literature, 37(3), 1120-1149. http://dx.doi.org/10.1257/jel.37.3.1120

Pose, A. R., \& Anne, K. (2009). Fiscal Decentralization and Economic Growth in Central and Eastern Europe, LEQS Paper No. 12, London School Economic and Political Sciene, Oktober, downloaded from http://www.lse.ac.uk/europeaninstitute/leqs/leqspaper12.pdf, at April, 5, 2014

Sacchi, A., \& Salotti, S. (2014a). The effects of fiscal decentralization on household income inequality: Some empirical evidence. Spatial Economic Analysis, 9(2), 202-222. http://dx.doi.org/10.1080/17421772.2013.833343

Sepúlveda, C., \& Martínez-Vázquez, J. (2011) The consequences of fiscal decentralization on poverty and income inequality. Environment and Planning C, Government and Policy, 29(2), 321-343. http://dx.doi.org/10.1068/c1033r

Simanjuntak, T. H., \& Imam, M. (2014). Analysis of fiscal decentralization and local fiscal impact on the performance and structure of local government spending as well as the welfare of the people of East Java, Research Report, Universitas Kristen Maranatha Bandung

Sukanto, M. (2013). Regional Fiscal Indepence, Poverty Rate And Welfare Society in South Sumatera Province, paper presenter on IRSA, Bandung 2-3 July

Tanzi, V. (1995). Fiscal Federalism and Decentralization: a Review of Some Efficiency and Macroeconomic Aspects. In M. Bruno and B. Pleskovic (eds), Annual World Bank Conference on Development Economics 1995. Washington, DC: World Bank.

\section{Copyrights}

Copyright for this article is retained by the author(s), with first publication rights granted to the journal.

This is an open-access article distributed under the terms and conditions of the Creative Commons Attribution license which permits unrestricted use, distribution, and reproduction in any medium, provided the original work is properly cited. 